\title{
Erhan Doğan and H Deniz Genç* Early-Responding Civil Society and a Late Coming State: Findings from Turkey during the Pandemic
}

https://doi.org/10.1515/npf-2020-0049

Received October 14, 2020; accepted January 3, 2021

Abstract: By building on available literature and interview notes with the NGOs working mainly on refugees and irregular migrants, this study examines the experiences of civil society in Turkey in the first 6 months of the COVID-19 pandemic. One of the main findings is that NGOs responded quite early and with agility to the sufferings of people before the state entered into the field and implemented its own rules and methods to deal with the crisis. The study also reveals that the pandemic affected the focus of the NGOs, their services, finances, and working methods in the field. The organizations we examined adapted to a new online working environment which increased demand for their services and aggravated difficulties in assuring clients access to needed healthcare services. The study finds that relations with the local and central governments remain difficult, and during the pandemic, the NGOs were compelled to act very cautiously. While suffering from their society's political polarization, they report that xenophobia continues to rise and has been worsened by the impact of the pandemic.

Keywords: civil society, Turkey, COVID-19, NGOs, migrants' access to healthcare, polarization, xenophobia, digitalization

\section{Introduction}

Turkey was stricken by COVID-19 just a bit later than were most other European countries. Even before the first case was diagnosed, Turkey's health authorities announced that the country was ready to fight with the virus. Though the health ministry has been criticized for the reliability of its statistical methods for keeping

\footnotetext{
*Corresponding author: H Deniz Genç PhD, Political Science and International Relations, Istanbul Medipol University, Beykoz, Istanbul, Turkey, E-mail: hdgenc@medipol.edu.tr

Erhan Doğan, Political Science and International Relations, Marmara Universitesi, Istanbul, Istanbul, Turkey, E-mail: edogan@marmara.edu.tr
} 
and reporting records on the pandemic, the health system seemed not have experienced an overload until the pandemic more fully established itself. At the time of this writing in late 2020, the number of confirmed cases and deaths is on the increase in the country, and Turkey has joined the global health crisis.

As the UNDP (2020: 2) notes, COVID-19 is much more than a health crisis; "it has the potential to create devastating social, economic, and political crises that will leave deep scars." In such times of crisis, NGOs and their activities become critical in reaching out to vulnerable people. As presented in this volume, NGOs are often at the forefront of COVID-19 efforts; they work to tackle the pandemic and support fragile and vulnerable communities. Throughout the pandemic, migrants have found themselves subject to particular stress. As noted by IOM (2020) and OECD (2020), migrants are more vulnerable than more settled persons in times of crisis because of the effects upon them of a confluence of personal, social, legal, and structural factors. They have socio-economic difficulties and difficulties in accessing healthcare, and they have to struggle with cultural and linguistic barriers, as well. They are reported to be more affected by the spread of COVID-19 in societies in which the pandemic is spreading. Moreover, in these times of crises, they may experience increased stigmatization and social exclusion (IOM 2020).

Turkey has been a land of diverse migrations (İçduygu and Kirişçi 2009). In the late 1970s, irregular migration became the main flow of migration to the country (Genç 2018). Since then the country has received waves of asylum seekers, the most recent wave has brought a mass migration of Syrian refugees since 2011. According to the website of Turkey's Directorate General for Migration Management, the number of Syrian refugees who are registered and under temporary protection is more than 3.6 million. ${ }^{1}$ In addition there are many Syrian refugees who remain unregistered and are not provided any proper legal status. Such irregular migrants lack access to any kind of formally provided services, including health.

Refugees and irregular migrants were among the first to be struck by the pandemic in Turkey. NGOs struggled to reach out to them and alleviate their problems. In line with the questions of this special issue, the main focus of this study is directed toward the study of the early impact of pandemic on NGOs working with migrants in Turkey. By building on in-depth interviews, the available literature, statistics and reports, the study examines the impact of the pandemic on the services, finances, and working methods of NGOs serving migrants in Turkey, and their relations with local and central government authorities. Following and introductory section on NGOs and civil society in Turkey, the study presents the analysis of our interview process.

1 Temporary protection is a status less than full refugee status, and in theory, it avails Syrian refugees to have access to basic rights such as education and health. 


\subsection{NGOs and Civil Society in Turkey}

Heper (2011) and Mardin (2006: 29) observe that a civil society in the Western sense - as "a part of the society that could operate independently of central government and based on property rights" did not emerge in the late Ottoman/early Turkish polity. In line with this view, Turkey has generally been described as a country whose civil society is relatively undeveloped. If one refers to a secular modern civil society in which property rights are guaranteed by the law and which is organized around associations that raise funds by means of membership fees and collect regular donations, this approach might be accepted as true. However, if we include traditional non-governmental groups which are organized around traditional institutions taking pre-modern values as reference, and which conduct their activities around pre-modern issues and with nonsecular motivations, one comes to the realization that Turkey's civil society is not all that weak. In terms of faith-based, charity-based, hometown-based or ideology-based NGOs, civil society in Turkey begins to demonstrate itself with modern forms and in richness and vibrancy. In Turkey, this type of civil society organization easily finds empty spaces in which it may conduct its work, as both local and central government authorities are not sufficiently capable, nor have they the adaptative capacity to assure prompt resolution of problems as they present themselves. It takes considerable time before the state addresses the problem area and develops comprehensive and structural solutions. The state in Turkey, like in other countries, learns first and then reacts after some period of time. In the pursuit of their organizational and programmed goals, it is important to note that civil society organizations defer to the positions and policies of state authorities. $^{2}$

In terms of legal framework, we can distinguish six main forms of NGOs in Turkey: (1) associations (dernek), (2) cooperatives (kooperatif), (3) chambers (oda), (4) foundations (vakff), (5) trade unions, and (6) civil servant trade unions. NGOs and non-profit organizations do not have a common legal structure but are usually established as either an association or a foundation (Kuzmanovic 2012: 8). According to Turkey's Ministry of Interior, there are 120.668 active associations (www. siviltoplum.gov.tr) and 5774 foundations (www.vgm.gov.tr) in Turkey. The majority of these associations perform activities involving social solidarity, religious services, education, and humanitarian aid, while foundations focus their activities on serving children (education included), the elderly, women, disabled persons, and the poor. Despite these forms, history, and numbers, NGOs in Turkey have struggled to survive

2 Some of the pro government NGO representatives openly referred to the point that one should not be in direct conflict with government to make some changes in the field. 
and retain their autonomy vis a vis a strong and centralized state which did not provide much room for autonomous groups to take root and act outside its authority (Heper 2011; Keysan 2019; Keyman and İçduygu 2003). Social groups were provided a greater space only when they accommodated to the center.

In the 1920s, NGOs were strictly restricted by several laws such as the Law for Maintenance of Public Order (1925) or the Labour Law of 1934. In the 1930s, the single party regime became more repressive and all autonomous societal forces, including NGOs have been suppressed. With the adoption of a more restrictive law in 1938, the state's repressions and restrictions on civil society continued unless compliance is demonstrated to 'the center' (Ahmad 1993; Anheier and Toepler 2009; Zihnioğlu 2011). During these early decades of the Turkish Republic, traditional faith-based entities were specifically targeted and closed, and pious foundations were strictly controlled by the state through the hands of Directorate General for Foundations. As the space of civil society was narrowed, many faith-based communities like religious orders retreated from the public space and became less visible.

By mid-1940s, 'the center' started to be balanced by the growing private sector and local leaders, who joined opposition against the single-party regime. In addition to these, the end of WWII brought new international dynamics which would contribute to the end of the single-party regime in Turkey and the creation of a pluralist, multi-party system (Ahmad 1993, pp. 201-214). In this context, civil society in Turkey found liberation. Following the amendment of the Law of Associations in 1946, many associations were developed, another law recognized the right of industrial workers to organize in unions in 1947, and in 1950, the transition to multi-party regime provided a fertile ground for all civil society organizations (Ahmad 1993; Zihnioğlu 2011). Although free organization of people had taken form by the early 1950s, the state, now controlled by the Democratic Party, continued to keep control of associations, foundations, labor unions, opposing media, and all other kinds of civil society actors, and it did not let them become active within the political arena (Mardin 2006). Restrictive attitudes and repressive measures returned in the second half of 1950s; Opposition, press, and universities were suppressed while the space for civil society organizations was severely limited (Ahmad 1993).

The first decade of the multi-party system in Turkey ended with military takeover in 1960. Following economic and political instabilities during the 1960s and 1970s, two other military interventions would follow this first one, and in each of them, except the one in 1960, military regimes would restrict and repress civil society. According to Doğan (2013: 61) the military regime between 1980 and 1983 "could be perceived as the ground zero, where all democratic institutions were banned" including most of the NGOs. In a similar vein, Şimşek (2004) shares numbers, following the 1980 coup, indicating that more than 20.000 of the existing 
38.354 NGOs were closed down by the military regime. In line with the restrictive and repressive approach of the military regimes, Turkish people associated civil society and the NGOs with negative meanings and they shied away from becoming active participants within civil society in the 1990s (World Values Survey 2007).

NGOs have had a rocky evolution in the Turkish society. The space allocated to them has been widened with every democratization effort, and then narrowed in every authoritarian turn. Anheier $(2017,19)$ shows that this is not something peculiar to Turkish society. A similar pattern has been reported in other countries with authoritarian regimes and/or illiberal democracies. Anheier's assessment of recent regulations and current proposals addressing civil society organizations in G20 countries clearly shows the increasing regulatory tendencies among these countries. In particular, it is clear that the illiberal democracies or authoritarian members of the $\mathrm{G} 20$ have been most restrictive on their regulations about the civil society. However, like in other authoritarian countries, civil society organizations in Turkey are tolerated as long as they provide welfare services and do not counter the hegemony of the state (Lewis 2013, 332; Spires 2011, 36).

Yet global, regional, national, and local developments in the late 1980s triggered rapid social/cultural, economic, and political change in the Turkish society. As Keyman and İçduygu (2003) note, one of the most important sites of change was civil society. While 'the strong state' was in a legitimacy crisis, civil society had been growing since the 1980 s and especially during the 1990s, and it contributed to the development of a more liberal and democratic society in Turkey. Kuzmanovic (2012, p. 6) argues that the revival of the civil society in Turkey should be discussed within the context of the general revival of civil society across the globe in the 1990s. The end of Cold War advanced neo-liberalism, which presented the empowerment of the civil society as the main route to turn societies into liberal democracies. International policy actors and donors, such as the EU, the UN, and the World Bank, embraced this international policy strategy of democratization as the main way to eliminate authoritarian state tradition and to reduce poverty in Turkey (ibid). According to many civic activists, the UN Habitat II Conference, which brought together hundreds of NGOs in Turkey in 1996, was a milestone for its civil society development (Kuzmanovic 2012; Zihnioğlu 2011). Moreover, the Marmara Earthquake activated many NGOs in 1999 (Kubicek 2002). And, in the same year Turkey was declared a candidate for EU membership. As EU candidacy necessitated the introduction of a liberal legal framework for civil society, it was expected to have a transformative impact on state-society relations. In addition, in order to empower NGOs, the EU provided financial and technical assistance during the 2000s (Zihnioğlu 2011). As it is noted before, in addition to the EU, IMF and World Bank also supported NGOs. As a result, 2000s witnessed a large increase in the numbers of NGOs in Turkey. 
It should also be noted that Turkey's EU candidacy and the later consolidation of political power in the hands of the Justice and Development Party (Adalet ve Kalkınma Partisi, AKP) from 'the periphery' challenged the center and provided a more liberal legislative environment for associations and foundations (Kuzmanovic 2012, 12). The new laws - the Law on Associations in 2004 and the Law on Foundations in 2008 - adopted by the AKP governments transformed the restrictive legal framework on civil society and provided a greater degree of freedom for NGOs. By 2000, the number of associations reached 72.378, it became 84.994 in 2010, and 120.632 in 2020 (www.siviltoplum.gov.tr, 2020). However, that increase in quantity did not transform itself in quality, and the impact of NGOs in making a real difference was limited (Kubicek 2002; Şimşek 2004). It is none the less important to recognize that civil society in Turkey underwent a substantial process of transformation in the 2000s.

NGOs in Turkey may be categorized on different criteria like their political stance, motivations, source of income, and relation to modernity. In line with these characteristics, there exist pro-government NGOs, and NGOs acting with opposition parties; faith-based NGOs such as pious foundations and religious orders, charities, secular modern NGOs; and hometown associations in the country. If we focus on their incomes we see government funded NGOs as well as foreign donor funded NGOs as well as NGOs that are supported directly and over a wide popular base in society. If we focus on their stance vis-à-vis modernity, we can identify NGOs such as women's associations, youth associations, and consumer protection associations among others, which focus their attention on specific issues and problems of modern societies. Religious orders and hometown associations, on the other hand, would be categorized as NGOs which do not appear to be directly motivated in modern directions. These non-governmental bodies frequently refer in their work to premodern values and institutions. However, these apparently historical references combine with operations in modern times and within modern institutional settings. Moreover, these associations are called upon to address effects of modernity at play within their communities. Therefore, their modes of operation can appropriately be described as hybrid.

\section{Method}

The first focus of our study is directed toward how NGOs functioned within the context of Istanbul's urban poverty during the pandemic. When we started to communicate with the NGOs that provide services for the urban poor, we found that refugees and irregular migrants had joined the ranks of most vulnerable and fragile people in the Turkish society, and that many NGOs were directing increased 
attention to their problems. In line with this, we directed our attention to NGOs working with migrants in Turkey. We addressed their experiences in the first 6 months of the pandemic in Istanbul. The impact of the pandemic on the focus of their services, finances, working methods, and relations with local and central government authorities make up the foci of this study.

Our study builds its analysis from an examination of interview notes, available literature, relevant sector reports, and news. We adopted qualitative research techniques and collected data through in-depth interviews. We employed purposive sampling and chose to interview representatives of NGOs which provide services to migrants (refugees, irregulars, regulars, foreign students) and urban poor. We contacted more than 15 NGOs, and found that six of them - Tarlabaşı Dayanışma, Derin Yolsulluk Ağı, Mülteciler ve Göçmenlerle Dayanışma Derneği, Mazlum-Der, Şefkat-Der, and Insani Yardım Vakfi - responded with willingness to be interviewed. We conducted the interviews in September 2020.

We coded interview notes independently by conducting complete coding and identified broad patterns (Braun and Clarke 2013; Saldaña 2015). After several rounds of discussions, data-derived codes were clustered together according to the similarity and the patterns they formed, and the following themes, which are presented in the analysis, were created: mismatch in the field, digitalization of the NGOs, tense relationship with the central government, neglect by local governments, political polarization as an obstacle, difficulty of accessing healthcare, and xenophobia fueled by the pandemic.

\subsection{COVID-19 in Turkey: Initiatives of Neighborhoods and Governments}

As the number of positive cases increased, the initial response of the Turkish government was the declaration of a curfew between 10 and 12 April 2020. This first curfew decision was followed by others. The aim was to decrease the pace of the spread of virus in the society. This measure was a new experience for the majority of the society. The curfew created new and unexpected problems, which aggravated the negative effects of the pandemic. Its side effects would be recognized soon.

People who were 65 and older were placed within the risk category and were not at all allowed to leave their places of residence. They were therefore not able to meet their own most basic needs. Neighborhood initiatives were initiated and volunteers in these loose neighborhood networks offered to do errands for their elderly neighbors, such as shopping or paying bills. This initiative created positive community spirit and widely appreciated as a positive element among 
all negativities of the pandemic. Traditional solidarity networks of Turkish society also became activated, but in the more urban locations they met only a fraction of the actual need. Clearly, a need existed for new and innovative solidarity activities.

The society expected the central government and local governments to act in this troublesome period, to provide new services and heal the wounds of the pandemic. The central government initiated a nationwide aid campaign to raise funds that would be spent for people in need. This campaign was supported by a number of pro-government business groups, the Turkish Chamber of Commerce, and some other entities affiliated with the government. Opposition groups criticized this initiative, observing that government is the established tax collector. These groups observed that asking taxpayers to donate the government, even though for the purpose of aiding people, was something odd, providing an unrealistic expectation of voluntary financial and physical efforts. The aid campaign "Biz bize yeteriz" (We are self-sufficient, Turkey) raised 1.960.239.000 TL (around 275.000 USD) and distributed aid to 1.960.239 families (1000 TL per family) (https://bizbizeyeteriz.gov.tr/).

Local governments are not customarily considered to be part of civil society. In the Turkish case, however, they are significant actors in the search for autonomy from the central government. Although they are kept under the tutelage, monitoring and control of the strong centralized government, they harbor centrifugal forces, groups, and ideas. In other words, they provide venues for groups at the periphery to search for alternatives from the strong-center (Erder and İncioğlu 2008). One political party, the Justice and Development Party (Adalet ve Kalkanma Partisi, AKP) has been ruling the country since 2002. In the 2010s, AKP governments have taken steps to further centralize the state, and later transformed the parliamentary system into a heavily centralized executive-style presidency in 2018. Despite this establishment of centralized power, for the first time since 2002, the AKP lost power in three major cities in 2019 local elections: Istanbul, Ankara, and İzmir, which constitute about half of Turkey's GDP (Sancak 2019). Not only in these cities, but control of municipalities of other major cities such as Adana and Antalya were also passed to opposition parties. The first year in office of these mayors, especially in Istanbul and Ankara, has been marked by tensions with the central government under President Erdoğan (Cagaptay and Yüksel 2020). On top of this, before their first year at office was over, COVID-19 was confirmed to have reached Turkey on 11 March 2020.

The opposition mayors, who now governed the most populous cities of Turkey, called for immediate containment measures. They 'spearheaded social efforts to battle the pandemic, launched fundraising campaigns, and encouraged citizens to wear masks in public' (Cagaptay and Yüksel 2020). As they were not rich with resources, nor were they able to levy new taxes, their fund-raising campaigns were to a certain extent considered normal compared to the central government's 
campaign. According to Moubayed (2020), the central government did not cooperate with opposition-run municipalities and it tried to limit their ability to distribute social assistance. In line with these efforts, the central government's response to calls for pandemic containment was delayed and fundraising campaigns launched by opposition mayors were declared illegal and banned on March 30. State banks blocked donation accounts, while President Erdoğan asserted that only the presidency had the right to raise funds (Butler 2020). The following day, Erdoğan introduced the central government's fundraising initiative (We are self-sufficient, Turkey - Biz bize yeteriz).

The opposition mayors resisted these limitations and pressures and spearheaded solidarity initiatives to provide assistance for individuals affected by the lockdown. One of these solidarity initiatives involved the campaign titled 'paying a neighbor's bill' (Askıda Fatura). After being blocked by the central government, the Istanbul Metropolitan Municipality, under Mayor Ekrem İmamoğlu's rule, started this initiative, in which a digital payment portal is provided for those citizens who want to pay water and gas bills of fellow burghers who had lost their livelihoods because of the pandemic. The municipality guaranteed donors that the invoices belonged to the people in need, developing a need evaluation system to provide this assurance. With this practice the municipality also increased its revenues as unpaid city water and gas bills were paid. Thus, was accomplished a triple win, not only for citizens and government, but later on, families in need, as the Istanbul Metropolitan Municipality added 'family support' and 'mother-kid support' packages to this initiative. In the period between May 4, 2020 and September 14, 2020, 180.174 bills amounting to more than 3.8 million dollars were paid in this way (https://askidafatura.ibb.gov.tr, Sept 15, 2020).

The Ankara Metropolitan Municipality launched a 'hot-meal for everyone campaign' on April 2, 2020, and started to deliver hot meals to people older than 65 , health-care personnel, and people in need in the capital city. As the municipality's fundraising campaign was blocked by the central government, the opposition mayor, Mansur Yavaş, called upon companies, philanthropists, and other municipalities to make in-kind contributions to the municipality's food bank. Another initiative of Yavaş was 'An iftar from me'. Islam's holy month of fasting, Ramadan, was in May, and the municipality acted as a bridge between the needy and philanthropists willing to buy an iftar (fast-breaking evening meal in the Ramadan) for a person in need. Citizens could send an iftar by paying $15 \mathrm{TL}$ (around 2 dollars) online to a website launched by the municipality: www.iftarver.com. Though the campaign started in Ankara, people from different cities started to make donations and the campaign was extended to all Turkey in a very short period of time. According to the web site of the municipality, 35.087 philanthropists funded 264.542 iftars in Ankara, and in total 73.787 people sent an iftar to 
more than a half a million people in all cities of Turkey (https://www.iftarver.com, Sept 16, 2020).

A limitation of these imaginative and innovative donation programs involved the very small (if any) number of refugees and irregular migrants who were able to benefit from these initiatives. The priority of local governments was their own citizen burghers. Moreover, it should also be noted that opposition parties, and therefore opposition mayors, have been critical of the central government's migration policies, and we believe that this contributed to the reflection of economic and social distress in the form of negative attitudes about migrants in the society (Erdoğan 2019).

\subsection{NGOs during the Pandemic}

According to the Third Sector Foundation of Turkey (Türkiye Üçüncü Sektör Vakfi, TÜSEV), a support network of over 100 associations and foundations, the spread of COVID-19 has adversely affected the activities of NGOs. In order to determine the problems experienced in this period, the network conducted a survey on the impact of COVID-19 outbreak on NGOs operating in Turkey (TÜSEV 2020). Their answers show that the main impact of the COVID-19 was on the activities organized by the NGOs: a majority of them had to cancel seminars, conferences, and performances; many noted that they had canceled training activities; and $43 \%$ of the respondents reported that they could not provide services because they had to end their field work and close down service centers. About one-third of the NGOs reported that they had to stop all of their activities, while $83 \%$ of the respondents reported an increase in demand for their services. Almost half of them noted that pursuing activities in other areas - such as healthcare needs, healthcare rights, online working systems training, poverty, and violence against women- came into their agenda. The pandemic affected aids and donations to the NGOs, too. Half of the respondents reported a decrease in the aids and donations they received (ibid.). When we complement this survey's findings with in-depth interviews with representatives from NGOs, several recurrent themes about the experiences of NGOs during the pandemic in Istanbul become clear. These themes are discussed in the following paragraphs.

Firstly, the interviewees reported a mismatch in the field: the number of people who asked for their services increased immensely. While the number of potential recipients has increased 'at least more than 10 times', the level of funding available decreased. According to the interviewees, refugee mothers and their children were desperate. In addition to refugees and asylum seekers, irregular migrants started to ask for their services. They asked for food, shelter, and help to access to healthcare. 
We know how Turkish citizens suffer from the pandemic. If the Turkish citizens are experiencing these difficulties, think about the immigrants, refugees, asylum seekers, especially those who are not registered. They are the most vulnerable group, they do not have any legal status, they are completely devastated. We can say that their number has increased many times. (Şefkat-Der, September 21, 2020).

The interviewees noted that irregular migrants were not among the people who asked for their services before the pandemic. In line with the studies, they described them as young and healthy people, who had been employed informally in different sectors. When the pandemic hit Turkey, curfew affected all sectors of economy including the informal, and it left many irregular migrants unemployed. According to the interviewees, under these circumstances many irregular migrants returned to their countries (if they were allowed and able), and many among those who deliberately stayed or found themselves stuck in Turkey began to ask for services.

After the pandemic, the numbers have seriously changed. I can say that the number of undocumented people who asked for help has increased by 10,000 percent. The number has increased a lot. This means that these people were really desperate. Among these, the number of young [healthy] people with strong physique who applied to us increased. People who are between the ages of 18-35 turned to us and asked for support. This age group does not appeal, this is very rare. (Tarlabaşı Dayanışma, September 23, 2020).

According to the interviewees, organizational budgets decreased as traditional donation flows dried up as well. Some former donors found that they had been transformed into people who themselves needed help.

Turkish citizens knew what to do during the curfew. They stayed in their houses, and while the government offices are not working, their applications have decreased. But there was no decrease in the applications of foreigners. Their problems continued and got worse. [On the other side] businesses were [also] affected. Donors could not donate, they could not support or sponsor to the activities of Mazlum-Der. Sources decreased, our expenses have also decreased. This way, we could survive. (Mazlum-Der, September 22, 2020).

Secondly, the interview notes revealed the digitalization of the NGOs. All of the interviewees expressed that they had to rely on online communication channels in order to serve their community during the lockdown. All have explained that social media channels have been used intensively. They set up WhatsApp groups, and collected needs through them. 
We asked [ourselves] what we can do. We thought we could start an exchange between people. [...] Then we started a WhatsApp group and started to match people there. Then we opened twitter, and then Instagram. I opposed Facebook. [...] So we continued with twitter, Instagram and WhatsApp. Young people in our group started to match people in need with supporters who sent messages via twitter or Instagram. That is how the Deep Poverty Network was established. (Derin Yoksulluk Ağı, October 3, 2020).

The networked organizations shared awareness-raising messages about COVID-19 via their Facebook and Instagram pages and updated their websites. Their beneficiaries asked for help through WhatsApp, and NGOs tried to link them with the experts and assistance through these channels. In several cases, they organized counseling or meeting sessions via Zoom. Though one of the interviewees asserted that the effectiveness of their work/service decreased when they worked online, it appeared to us that they did their best and adapted to a new online working environment very quickly.

Thirdly, almost all interviewees, except the pro-government ones, explained that they had a tense relationship with the central government. All interviewees have noted that they were not able to receive any funding or any kind of contribution from the central government during the lockdown. Several interviewees noted that local branches of the central government ignored their effectiveness in the field.

We explained this through social media and other media channels, we went to the district governors. The governors did not give us an appointment. District governors have insulted us. We did not want to seem to be doing great things, we did not say such a thing. We just tried to give recommendations about these people, they are desperate. (Tarlabaşı Dayanışma, September 23, 2020).

None of the interviewees, including the pro-government ones, reported a close relationship with the central government and they described the relationship between NGOs and the central government as a rocky one. We understand that following the transformation of the parliamentary system into a heavily centralized executive-style presidency in 2018, the state became more authoritarian, and the legal and regular venues for the flexible development of NGOs have shrunk. In referring to this development, interviewees underlined the difficulties they came across in their fundraising activities. Although they had the right to raise funds for their services under law, according to several of them the central government controlled, limited, and sometimes prohibited their fundraising activities.

If we hadn't been careful, they might have stopped our work somehow. You know that the Metropolitan Municipality started a fund raising initiative, then the central government stopped it. Perhaps my field experience helped us. I tried to act cautiously, [I told that] we should act very slowly, let's not be visible, we are a network of solidarity. (Derin Yoksulluk Ağı, October 3, 2020). 
One of the interviewees explained that when an NGO publicly criticizes the government for its policies, visits from Ministry of Interior inspectors to examine their papers, and possibly even prosecution, may be expected.

The target should be zero in violence. Other than that, everything else is a failure. [...] I criticized the government and I was put on trial for that. I mean, I was sued and I was even found guilty. When you criticize the officials, the Directorate of Associations and the Ministry of Internal Affairs send their inspectors immediately. But we talk a lot, I criticize it because this is one of the most important features of our association: justice. (Şefkat-Der, September 21, 2020).

Moreover, in line with the centralized strong-state tradition, the interview notes revealed that acting ahead of the state seems unacceptable to the central government. We concluded that, whenever this occurs, even though the organization may be providing services to vulnerable and fragile people that the state fails to serve, the central government moves to deactivate the NGO because it is seen to cause the perception that the state is incapable of providing those services:

Even for those associations which are not political can have problems. Officials do not like an atmosphere of 'we are doing better than the state'. (Şefkat-Der, September 21, 2020).

In line with their experiences in the field, interviewees criticized the central government for not striving enough to reach out to migrants and refugees. Though Turkey's open door policy for the Syrian refugees is widely celebrated within the NGO community, most of its members criticize aspects of this policy-the temporary protection status, detention centers, the decision to open the borders for migrants to cross into the European Union, and repatriation of irregular migrants and some Syrians:

Turkey gives refugees a special status. This is not in compliance with international law. Statuses such as temporary protection, actually these statuses are made up to bypass the refugee status. Groups, which were once granted special statuses for certain political considerations, can suddenly become targets [of anti-immigrant attitudes, political discourses] when the conjuncture changes. Mazlum-Der is trying to prevent deportation of migrants from Detention Centers. We are trying to help Syrians for their residence permits [...] (Mazlum-Der, September 22, 2020).

These critical views held that migration policies of the government became more impractical during the lockdown as they failed to provide services to refugees and migrants in the field. In addition, government agencies working on migration were temporarily closed. Interviewees explained different outcomes of this temporary closure. According to the interviewee from Göçmen Dayanışma Derneği, the closure/lockdown of the government agencies paralyzed the services provided to 
the refugees. ${ }^{3}$ Differently from this, the interviewee from Mazlum-Der explained that refugees and irregular migrants' rights could not be violated as the government and law enforcement agencies were inactive. As he explained as an example, the irregular migrants could not be deported during the lockdown. ${ }^{4}$

When the interviewees were asked about their relationship with the local governments before and during the pandemic, they reported that they were neglected by them. All interviewees except one explained that they did not receive any support from local government. The interviewee from the Göçmen Dayanışma Derneği (Migrant Solidarity Network) stated that they cooperated and were supported by the local government in their operations and activities. ${ }^{5}$ But other than this, they did not receive any funding from the local authorities. When we asked about the Istanbul and Ankara Metropolitan Municipalities' campaigns - 'paying a neighbor's bill' and 'hot meal for everyone', interviewees noted that these campaigns, 'paying a neighbor's bill' in particular, asked personal details of the people in need. Therefore irregular migrants were afraid and did not apply for the assistance in paying their bills. $^{6}$

Municipalities wanted to consult with us once. We shared our practices, but similar to the NGOs, municipalities in Turkey also do not have the infrastructure, the legal bases, and the understanding to provide solutions. This may happen because of the bureaucracy, or because the municipality is governed by the opposition party. They are not effective in the field. [...] For example 'paying a neighbor's bill' campaign asked for too much details. The person is already a refugee and he is afraid. If I asked this person to fill the online form with all his information, he would be suspicious of me. (Tarlabaşı Dayanışma, September 23, 2020).

The interviewee from Tarlabaşı Dayanışma explained their model of organization in the field and how they linked philanthropists with irregular migrants and refugees in need. He explained that they shared this model with the local government but found that their input was neglected. ${ }^{7}$ The other interviewees also shared similar experiences about the attitude of the local governments. Differently from all interviewees, the interviewee from Derin Yoksulluk Ağı stated that their model to match donors and the people in need was later adopted by the Istanbul Metropolitan Municipality. ${ }^{8}$ But, in general, the interviewees reported that local governments failed to provide services to the people including the migrants:

3 Interview Notes, Göçmen Dayanışma Derneği, September 25, 2020.

4 Interview Notes, Mazlum-Der, September 22, 2020.

5 Interview Notes, Göçmen Dayanışma Derneği, September 25, 2020.

6 Interview Notes, Tarlabaşı Dayanışma, September 23, 2020; Derin Yoksulluk Ağı, October 3, 2020.

7 Interview Notes, Tarlabaşı Dayanışma, September 23, 2020.

8 Interview Notes, Derin Yoksulluk Ağı, October 3, 2020. 


\begin{abstract}
Let me say this, I am not trying to discredit the mayor, but all municipalities, including ours, including İstanbul Metropolitan Municipality, failed. I am saying this frankly. Because the hunger of a baby cannot wait for the bureaucracy, for the legislation. You throw that legislation to the garbage and do something. The person calls me and says that she can give only water with sugar to her baby. This is hunger. [...] After the pandemic all local governments will need to think about what is wrong with their social services legislation. They should question what is wrong [so] that they could not provide any services. But they do not do that, they say they did a great work! (Derin Yoksulluk Ağı, October 3, 2020).
\end{abstract}

Interviewees reported political polarization as a main obstacle for their operations. Polarization has been one of the key characteristics of Turkish politics for decades. However, recent public opinion surveys report an alarming level of polarization in the Turkish society (KONDA Barometresi Kutuplaşma 2019: 11; KONDA 2018). ${ }^{9}$ As the interview notes reveal, polarization has been counterproductive for the NGOs. The interviewees stated that they had to act very cautiously and that they tried to remain out of politics. Otherwise they were suppressed by the central government, their applications delayed, their fundraising campaigns declared illegal, and their usage of local government facilities restricted, etc. Two interviewees expressed that when they criticized the government, their accounts were examined by the inspectors from the Ministry of Interior. Even the interviewees from NGOs known as pro-government claimed that whenever they criticized government or state institutions, they felt they were being ostracized by the relevant state authorities and their networks. Similarly, the NGOs which are affiliated with the opposition shared similar experiences with the local governments governed by opposition parties. Their statements revealed that political polarization narrowed their space and affected their operations negatively. In the end, all interviewees underlined that they wanted to be autonomous from politics and asserted their wish to provide services for their target groups without being affected by the political polarization in the country.

Another issue related to the high degree of politicization of their activity area was identified by the interviewees as the difficulty of accessing healthcare for migrants during the pandemic. They noted that access to healthcare was already very difficult and problematic for the refugees and irregular migrants in Turkey, and that the pandemic problematized it further. ${ }^{10}$

9 https://konda.com.tr/wp-content/uploads/2020/08/TR1901_Barometre94_ TurkiyedeKutuplasma.pdf.

10 Interview Notes, Göçmen Dayanışma Derneği, September 25, 2020; Tarlabaşı Dayanışma, September 23, 2020; Mazlum-Der, September 22, 2020. 
The biggest risk lies with the undocumented migrants right now. Their situation is worse than terrible. I cannot find a word to describe. Here we are trying to do something with the special efforts of some NGOs and some individuals, but it is not possible to catch up with their needs. I cannot explain it. I think about their state of health, their sicknesses. I know that many of them cannot even go to the hospital because they hesitate. [...] Undocumented migrants are already afraid to go to hospital, they cannot take the PCR test. The doors are closed. They go only if it is a matter of life and death (Şefkat-Der, September 21, 2020).

Though Syrian refugees, who are registered and under temporary protection, possess the right to access health services, unregistered Syrians and irregular migrants do not have access to regular health care. As the interviewees noted, the governorship of Istanbul took two important decisions for the Syrian refugees in Istanbul in July 2019: it stopped the registration of Syrians in Istanbul and removed those registered in other cities of Turkey to their original registration cities. These decisions paralyzed many Syrians who have been trying to settle in Istanbul. As they were already in fear about being sent to other cities, they were already experiencing difficulties blending into society before the pandemic. They tended to access healthcare only through informal channels such as informal clinics set up by Syrian doctors and sometimes through private clinics and private hospitals which turned a blind eye toward them. Similarly to the situation of the Syrian refugees, who are not registered in Istanbul, other irregular migrants do not have legal access to healthcare. When it is urgent, they seek health in private clinics and private hospitals. $^{11}$

Interviewees reported that they prepared information leaflets in different languages, sent awareness-raising messages through WhatsApp groups, distributed masks, hand sanitizers, and sanitary gloves. Moreover, these NGOs tried to find informal solutions to the health needs of the people who asked for their services. They directed them to the private hospitals with which they had been cooperating. They organized Zoom sessions with doctors. In cases where online solutions did not work, they directed persons in need of service to doctors in their informal networks. When we asked whether there were any COVID-19 cases among the people who asked for their services, none of the interviewees responded. But they all asserted that refugees, and irregular migrants in particular, were so afraid that they would never go to a hospital if they thought that they carried the symptoms. ${ }^{12}$

11 We share partial findings from the field study, which is supported by Scientific and Technological Research Council of Turkey (TÜBİTAK) under Grant 118K345.

12 Interview Notes, Göçmen Dayanışma Derneği, September 25, 2020; Tarlabaşı Dayanışma, September 23, 2020; Şefkat-Der, September 21, 2020. 
Lastly, almost all interviewees have noted that the pandemic fueled xenophobia in Turkey. They underlined that anti-immigration attitudes have been on the rise in Turkey in general and in Istanbul in particular. They shared different anecdotes about the xenophobic incidents that refugees and migrants have been experiencing in the form of anti-immigrant attitudes. According to the interviewees, due to the economic crisis in the country, xenophobia was already on the rise before the pandemic. However, in their view, as the economic crisis worsened in the onslaught of the pandemic, anti-immigrant attitudes increased and xenophobia also rose. ${ }^{13}$ We were led to understand that this development did not only affect the fundraising activities of the NGOs, but also their operations in the field. Several of the interviewees told of experiencing verbal attacks directed toward them while they were in the field distributing food and other needs to irregular migrants during the lockdown:

We feel it in the field. Once we were in a street, we were talking, motivating irregular migrants, who are African, a lady from the next building shouted us 'go away, you scum' [...] Then police came. She called them. There are many others, they threaten us, they do not want us to visit their neighborhoods, they warn us about migrants because 'they steal their jobs'. Numerous messages were sent from social media. [...] In addition, during the pandemic, landlords expelled migrants from their homes, by saying that "go away you scum, you will infect us". People were thrown into the streets. They were paying their rents. They give no harm. They do not even leave the house. (Tarlabaşı Dayanışma, September 23, 2020).

In addition, two of the interviewees shared the xenophobic messages written to their Facebook pages with us. The words of the interviewee from Şefkat-Der described the position of the majority of the Turkish society about immigration in Turkey and also their approach to the operations of NGOs working in this field:

I have been working in the civil society for more than twenty-five years. For the first time in the last four - five years, the responsiveness of the society has fallen behind the responsiveness of the state. Turkish people used to pity migrants, refugees, war victims, Africans, etc. and they pressured the state to act. They used to be more responsive than the state. Now they see Syrians and Afghans as the reasons of their economic and other problems. And unfortunately, [there is] discrimination, exclusion, and otherization of the migrants. ${ }^{14}$

\section{Conclusion}

In the light of our analysis, we conclude that, the pandemic and the overlapping economic crisis have deeply affected Turkey's lower classes, underclass, and

13 Interview Notes, Şefkat-Der, September 21, 2020; Tarlabaşı Dayanışma, September 23, 2020; Göçmen Dayanışma Derneği, September 25, 2020; Mazlum-Der, September 22, 2020.

14 Interview Notes, Şefkat-Der, September 21, 2020. 
invisibles - its refugees and irregular migrants. NGOs which are providing services to these groups have been overwhelmed by the number of people who sought their services and by the tasks asked from them. In response to these challenges, with decreasing funds in hand, they have been required to change their modus operandi and adopt new strategies, such as using technology to collect needs, disseminate information about the pandemic, raise funds, and link donors with recipients. In so doing, they have not been able to attract visible support from central and local government authorities. They find themselves neglected.

In times of crisis as those of pandemic, pluralist and social democratic visions tend to fade, and governments seek to take advantage of emergencies to further strengthen their positions vis-a-vis civil society by further advancing authoritarian forms and structures. In the Turkish case, in which the state is already marked in the 'strong state' tradition and by the recent transformation to a heavily centralized executive-style presidency, the room for civil society maneuver has already been narrowed. As the interview notes reveal, the pandemic put the latest nail in the coffin. The central government declared fundraising campaigns of municipalities illegal, and tried to control the distribution of social assistance for persons affected by the lockdown. Though expected to play an implicit, invisible role in general, pro-government NGOs sought to act with the authorities during the pandemic. The work of almost all NGOs has been governmentally neglected, except these pro-government ones. This differential approach to the NGOs is closely linked with the political polarization in the country but all interviewees, regardless of the ideological position of their NGO, complained in a varying degree that they were not able to operate fully in the field due to the polarization.

The NGOs whose work is central to this paper have diligently and persistently struggled throughout the pandemic with the pre-existing problem of facilitating access to healthcare among Turkey's migrants. They devised new strategies and acted as bridges between refugees and irregular migrants in need and government authorities and health system. Our study indicates, by noting deficiencies of the migration policies, the steady rise of xenophobia in Turkey. The testimony of our respondents indicates how fully the economic crisis had already affected Turkish attitudes about migrants, and this situation has now been considerably worsened with the impact of the pandemic. Our interviewees describe a crisis in which their efforts to serve a population in need becomes increasingly difficult. Both central and local government authorities have been and continue to be slow to respond to the crises occasioned by both migration and poverty. These governmental institutions remain distant from populations that desperately need their service. Whatever their party, they have failed to comprehend obligations to assist their national and municipal constituents and residents in need. And, all the while, NGOs from diverse ideological backgrounds continue with their efforts to lessen 
the destructive effects of the pandemic in the field, the resources dedicated to their efforts in steady decline.

When we put Turkish experience into a global context, we note that in line with the experiences of civil societies of similar regimes, Turkish civil society suffers from authoritarian practices of individual and institutional government authorities in particular and the political system in general. How the NGOs respond to these restrictive and repressive regimes has been described by Anheier (2017) and others, and. the Turkish case generally follows the global pattern. However, this study notes that Turkey has a big, vibrant, strong and nominally less politicized civil society which is mainly preoccupied with practical problems. Those problems are addressed very slowly by the state, which requires a long learning and adaptation process. We think that this opens a window of opportunity for civil society actors who act as pioneers in a problematic area until the state learns and adapts itself. When the state inserts itself into the field, civil society actors tend to withdraw. And over time, the state narrows down the space that was once filled by civil society. The Turkish case shares this scenario with other similar political regimes. Still, the unique solutions, reaction speed, and style of Turkish civil society organizations in the Covid-19 experience may offer lessons to other countries.

\section{References}

Ahmad, F. 1993. The Making of Modern Turkey. London: Routledge.

Anheier, H. K. 2017. "Civil Society Challenged: Towards an Enabling Policy Environment. Economics: The Open-Access, Open-Assessment E-Journal 11: 1-20.

Anheier, H. K., and S. Toepler, eds. 2009 International Encyclopedia of Civil Society. New York: Springer Science \& Business Media.

Braun, V., and V. Clarke. 2013. Successful Qualitative Research: A Practical Guide for Beginners. London: Sage.

Butler, D. 2020. Coronavirus Stokes Tensions between Erdogan and Istanbul's Mayor. Reuters. https://www.reuters.com/article/us-health-coronavirus-turkey-istanbul-idUSKBN21/50Z (accessed September 14, 2020).

Cagaptay, S., and D. Yüksel. 2020. Turkey's COVID-19 Response. The Washington Institute. https://www.washingtoninstitute.org/policy-analysis/view/turkeys-covid-19-response (accessed September 12, 2020).

Doğan, E. 2013. "Changing Motivations of NGOs in Turkish Foreign Policy Making Processes: Economy, Identity, and Philanthropy." International Review of Turkish Studies 3 (1): 56-81.

Erder, S., and N. İncioğlu. 2008. Türkiye'de Yerel Politikanın Yükselişi: İstanbul Büyükşsehir Belediyesi Örneği, 1984-2004. İstanbul: Bilgi Üniversitesi Yayınları.

Erdoğan, M. 2019. Türkiye'deki Suriyeli Mülteciler. İstanbul: Konrad Adenauer Vakfı.

Genç, H. D. 2018. "Responding to Irregular Migration: High Potential of Local Governments in Turkey.” International Migration 56 (3): 73-87. 
Heper, M. 2011. "Review: The Transformation of Turkey: Redefining of State and Society from the Ottoman Empire to the Modern Era." The Middle East Journal 66 (2): 377-9.

İçduygu, A., and K. Kirişci, eds. 2009 Land of diverse migrations: Challenges of emigration and immigration in Turkey, Vol. 10. İstanbul: Istanbul Bilgi University Press.

IOM. 2020. Migration Factsheet No. 6 - The Impact of COVID-19 on Migrants. https://www.iom.int/ sites/default/files/our_work/ICP/MPR/migration_factsheet_6_covid-19_and_migrants.pdf (accessed December 12, 2020).

Keyman, E. F., and A. İçduygu. 2003. "Globalization, Civil Society and Citizenship in Turkey: Actors, Boundaries and Discourses." Citizenship Studies 7 (2): 219-34.

Keysan, A. Ö. 2019. Activism and Women's NGOs in Turkey: Civil Society, Feminism and Politics. London: I.B. Taurus.

Kubicek, P. 2002. "The Earthquake, Civil Society, and Political Change in Turkey: Assessment and Comparison with Eastern Europe." Political Studies 50 (4): 761-78.

Kuzmanovic, D. 2012. Refractions of Civil Society in Turkey. New York: Palgrave Macmillan.

Lewis, D. 2013. "Civil Society and the Authoritarian State: Cooperation, Contestation and Discourse." Journal of Civil Society 9 (3): 323-40.

Mardin, Ş. 2006. Religion, Society, and Modernity in Turkey. New York: Syracuse University Press.

Moubayed, S. 2020. “Has Turkey Mishandled its Coronavirus Response?" European Eye on Radicalization. https://eeradicalization.com/has-turkey-mishandled-its-coronavirusresponse-2/(accessed September 14, 2020).

OECD. 2020. What Is the Impact of the COVID-19 Pandemic on Immigrants and Their Children? https://www.oecd.org/coronavirus/policy-responses/what-is-the-impact-of-the-covid19-pandemic-on-immigrants-and-their-children-e7cbb7de/(accessed December 12, 2020).

Saldaña, J. 2015. The Coding Manual for Qualitative Researchers. Thousand Oaks, CA: Sage. Sancak, M. 2019. Reading the Results of the 2019 Local Elections in Turkey. Sheffield: Speri.

Şimşek, S. 2004. “The Transformation of Civil Society in Turkey: From Quantity to Quality.” Turkish Studies 5 (3): 46-74.

Spires, A. J. 2011. "Contingent Symbiosis and Civil Society in Authoritarian State: Understanding the Survival of China's Grassroots NGOs." American Journal of Sociaology 117 (1): 1-45.

TÜSEV 2020. The Impact of COVID-19 Outbreak on Civil Soviety Organizations Operatings in Turkey. Survey Report April 2020. https://www.tusev.org.tr/en/news/the-impact-of-covid19-outbreak-on-civil-society-organizations-operating-in-turkey-survey-report-ispublished\#.X0-JQC3BJE9 (accessed September 2, 2020).

UNDP. 2020. COVID-19 Pandemic: Humanity Needs Leadership and Solidarity to Defeat the Coronavirus. https://www.tr.undp.org/content/turkey/en/home/coronavirus.html (accessed December 13, 2020).

World Values Survey. 2007. www.worldvaluessurvey.org (accessed September 16, 2020).

Zihnioğlu, Ö. 2011. Europeanization of Turkish Civil Society Organizations during the Accession Process to the EU: A Gramscian Analysis. Unpublished PhD Thesis. İstanbul: Boğaziçi University. 